\title{
Financial Disclosure and Budgetary Practices of Religious Organization: A Study of Qaryah Mosques in Kuala Terengganu
}

\author{
Shahida Bt Shaharuddin ${ }^{a^{*}}$ and Maliah Bt Sulaiman ${ }^{b}$ \\ ${ }^{2}$ Faculty of Law, Accountancy and International Relations, Universiti Sultan Zainal Abidin, Malaysia \\ ${ }^{b}$ Kuliyyah of Economics and Management Sciences, International Islamic University Malaysia
}

\begin{abstract}
This paper aims to examine the financial reporting and budgeting practices of qaryah mosques in Kuala Terengganu, a state in the east of Peninsular Malaysia. Data was collected using a mixed method (quantitative and qualitative) approach. The questionnaire was disseminated to qaryah mosques in Kuala Terengganu and 39 responded. To address the limitations of a questionnaire survey, semi-structured interviews were then conducted with a few of the respondents. The results revealed that qaryah mosques in Kuala Terengganu do have a satisfactory system in place in terms of their financial reporting practices. However, budgetary control practices appear to be lacking. This indicates accounting, as is practiced by qaryah mosques in Kuala Terengganu appears to be limited to financial accounting. Hence, the financial management in qaryah mosques needs to be improved so that the risk of embezzlement can be reduced.

Abstrak: Penelitian ini bertujuan untuk menguji pelaporan dan penganggaran praktek keuangan masjid-masjid qaryah di Kuala Terengganu, Negara bagian di timur Semenanjung Malaysia. Pengumpulan data dilakukan dengan menggunakan metode pendekatan campuran (kuantitatif dan kualitatif). Kuesioner disebarkan ke masjid-masjid qaryah di Kuala Terengganu dengan jawaban yang diterima sebanyak. 39. Untuk mengatasi keterbatasan survei kuesioner, kemudian dilakukan wawancara semi-terstruktur dengan beberapa responden. Hasilpenelitian menunjukkan bahwa masjid-masjid qaryah di Kuala Terengganu memiliki sistem yang memuaskan dalam hal praktek pelaporan keuangannya, namun, nampaknya kurang dalam praktik kontrol anggaran. Hal ini menunjukkan babwa akuntansi, seperti yang dilakukan oleh masjid-masjid qaryah di Kuala Terengganu tampaknya hanya terbatas pada akuntansi keuangan. Oleb karena itu, manajemen keuangan di masjid-masjid qaryah perlu ditingkatkan sehingga risiko penggelapan dana dapat dikurangi.
\end{abstract}

Keywords: accountability; budgets; financial reporting; qaryah mosques; religious organizations

JEL classification: M4

* Corresponding author's e-mail: shahidashaharuddin@unisza.edu.my 


\section{Introduction}

Accounting malpractice in religious organizations has affected the credibility of such organizations. In a recent case, a finance administrator at Chester United Methodist Church was charged with embezzling more than $\$ 500,000$ from the church (Remmers 2013). The same phenomenon has also occurred in other religious organizations, and in mosques. A former collector of tithes pleaded guilty to committing a criminal breach of trust involving RM19,510 (Hafidzin 2011). Religious organizations and mosques are regarded as 'sacred' and people who worked there or are associated with them are perceived to have high moral values. However the increase in financial scandals, like the misappropriation of funds, amongst these institutions is still baffling. Most of these misappropriations are brought about by poor accounting and internal control practices (Abdul Rahman and Goddard 1998; Bowrin 2004 and Sulaiman et al. 2008). The same holds true for mosques in Kuala Terengganu (a state in Malaysia that has a population who are more than $96 \%$ Muslim) and indeed it is an interesting issue to pursue. This is precisely what this paper attempts to address. It sets out to investigate the financial accounting and budgeting practices of qaryah mosques in Kuala Terengganu. This study scrutinizes the preparation of accounts, which includes reporting (here disclosure) and budgets by the qaryah mosques, and aims to answer the following research questions.

RQ 1: Do mosques in Kuala Terengganu prepare accounts and disclosed them to the qaryah members?

$\mathrm{RQ}$ 2: What is the extent of disclosure practices by qaryah mosques?

RQ 3: Do mosques in Kuala Terengganu prepare budgets?
RQ 4: What is the extent of budgetary practices by qaryah mosques?

Our study adds to the literature by reducing the dearth in the study of accounting and budgeting practices at religious institutions like mosques. Our study extends the work of Siraj (2004) which focused on the state mosques, while we examine the accounting and budgeting practices of qaryah mosques. This is important as qaryah mosques are mostly located in residential areas and are closer to their local communities. Compared to other types of mosques, members of qaryah mosques normally consist of residents within the mosque's vicinity and they tend to accommodate a large number of worshippers.

Qaryah mosques are totally funded by qaryah members and guest worshippers through donations. (Said et al. 2013). The large amounts of donations received by qaryah mosques may give rise to misappropriation should there be no proper internal control (Sulaiman et al. 2008; and Wooten et al. 2003). Examining the financial management practices of these organizations would indeed be important, as the results may provide information for these mosques to address any problems they have in the management of their funds. Having the largest number of qaryah mosques compared to other districts in Terengganu, Kuala Terengganu would provide a richer data source for our questionnaire survey, as the larger the sample, the better it is for statistical analysis and to be able to make generalizations.

The remainder of the paper is structured as follows. The next section elaborates on the accounting practices in Islamic religious organizations. Section 3 discusses the administration of Islamic affairs in Malaysia while section 4 explains accounting and the concept of accountability as it applies to Islamic 
religious organizations. Section 5 focuses on the research method while the analysis and findings are discussed in section 6. Section 7 concludes.

\section{Accounting Practices in Islamic Religious Organizations}

Good financial management requires adequate financial control since it is important for organizations, including religious organizations, so that public funds will be taken care of (Siraj 2004; and Agus et al. 2009). However, prior studies have found evidence that there exists poor accounting practices and a lack of internal control in religious organizations (Abdul Rahman and Goddard 1998; Duncan et al. 1999; Ahmad et al. 2001; Bowrin 2004; and Sulaiman et al. 2008). While there have been many studies focusing on Western church organizations (Woodbine 1997; Duncan et al. 1999; Duncan and Flesher 2002; Parker 2002; Wooten et al. 2003; Bowrin 2004; Elso et al. 2007; and Ventura and Daniel 2010), studies on mosques are lacking. The study by Sulaiman et al. (2008) on the financial management of state mosques in Malaysia is indeed, commendable. They found that there were strong internal controls in the receipt and disbursement of funds in Peninsular Malaysia's state mosques. However, Siraj (2004), found less than satisfactory use of their budgets and reporting. The results appear to be consistent with that of Wooten et al. (2003). In their study on churches, they found adequate controls over cash receipts but weaknesses in their disbursement and reporting. Further, Ahmad et al (2001) and Mohamed-Adil et al. (2012), in their study examining the efficiency of fund management by mosques, found that most of the mosques relied on public donations to get their funds. However, such mosques failed to invest the funds to earn more income.

\section{Factors Influencing Accounting Practice in Religious Organizations}

There are several issues that have been commonly discussed in prior studies to explain accounting practices in religious organizations. These include the distinction between the sacred and the secular (Laughlin 1988; Booth 1993; Woodbine 1997; and Parker 2002), the high trust environment within the organizations (Throop 2001; Duncan and Flesher 2002; Wooten et al. 2003; Busby 2004; Busby 2005; Jayasinghe and Soobaroyen 2009; Afifuddin and Siti Nabiha 2010; Ventura and Daniel 2010; and Enofe and Amaria 2011), the person in charge of the financial management of the religious organization lacking a financial management background (Duncan et al. 1999; Duncan and Flesher 2002; Parker 2002; Wooten et al. 2003; Elson 2007; Sulaiman et al. 2008; Ventura and Daniel 2010; and Enofe and Amaria 2011) and the lack of the element of the "involved owner" (Duncan et al. 1999; Ventura and Danie 2010; and Afifuddin and Siti Nabiha 2010).

\section{Between the Sacred and the Secular}

Accounting was initially not considered important in the church due to the distinction made between the sacred and the secular (Laughlin 1988; and Morgan 2009). The dichotomy between sacred and secular activities placed accounting as a secular activity. Accordingly, accounting cannot be practiced together with the sacred activities of the church (Laughlin 1988; and Booth 1993). The existence of a sacred secular divide in church organizations is, however, not supported by the results from studies conducted by some other scholars. Jacobs (2005), for 
example, provides evidence that although the jurisdictional conflict between accountants and the clergy contribute to the resistance of accounting practice in the church, it does not mean that accounting is not necessary. People in the church prefer accounting activities to be undertaken by someone with a religious connection such as the clergy (even though they are not adequately qualified). Accountants may give advice but they should not be put in control. Irvine (2005) also found that the need for accounting to achieve the sacred mission of the church organization is pertinent. Thus, the resistance to accounting, in principle, is minimal. Theoretically, the issue of the sacred and secular divide does not exist in Islamic organizations. According to Islamic teachings, there is no dichotomy between the worldly life and the hereafter (Abdul-Rahman and Goddard 1998) and the Islamic concept of accountability does not recognize the distinction between the sacred and the secular (Sulaiman et al. 2008).

\section{The Issue of Trust}

It is believed that nonprofit organizations have an environment of high trust which makes them vulnerable to fraud and abuse (Ventura and Daniel 2010). Many nonprofit organizations, particularly in the case of religious organizations, assume a high level of morality among their members and staff (Bowrin 2004; Jayasinghe and Soobaroyen 2009). Given this, 'secular' controls, such as accounting, appear not to be important. Trust is one of the factors that contribute to the mismanagement of funds. In many embezzlement cases, trust is misplaced in the embezzler (Elson 2007). Such a high level of trust will lead to very little need for supervision. This would, in turn create opportunities for fraud (Ventura and Daniel 2010). The study conducted by Sulaiman et al. (2008) provides further evidence that the element of trust renders internal controls unnecessary. Subsequently, this may provide an opportunity for fraud and also fraud that is difficult to detect, given that the perpetrators are "trusted" individuals.

\section{Lack of Accounting and Financial Management Background}

Another factor that contributes to the poor accounting practices of religious organizations is due to the fact that people who handle the financial management of such organizations lack an accounting and financial management background (Enofe and Amaria 2011). With reference to Duncan et al. (1999), the educational background of the treasurer in the church contains little or no training in business management or accounting. In fact, a study conducted by Elson et al. (2007) found that church accounting personnel do not really know the requirements for preparing financial reports using generally accepted accounting principles. This is not peculiar to church organizations. Mosques too face the same problem. This is evidenced in the study of Sulaiman et al. (2008). They found that the absence of certain control systems in state mosques is due to a lack of accounting knowledge of the persons entrusted with mosque funds. More specifically, the treasurer has insufficient knowledge concerning the importance of the relevant internal controls.

\section{Involvement of Volunteers}

The high levels of involvement by volunteers may yet be another important contributory factor to the mismanagement of funds in religious organizations. Most financial programs of religious organizations are handled by volunteer treasurers, who might lack skills in internal control design and information system development (Wootenet al. 
2005; Ventura and Daniel 2010). Additionally, given the inadequate training provided for volunteer treasurers on accounting matters, it is not surprising that there exits improper accounting practices and poor internal controls in religious organizations.

\section{The Lack of the "Involved Owner"}

Unlike businesses, non-profit organizations are non-stock entities where the ownership rests with the members or supporters of the organization. The absence of stock ownership may affect the management control process because managers might not consider themselves as accountable to donors as they would to the owner (Duncan et al. 1999). According to Ventura and Daniel (2010), the lack of an involved owner in monitoring the financial condition of the organization as a matter of self-interest may result in a lack of financial control and poor financial management, which will then create the opportunity for fraud. Churches, temples and mosques are among the nonprofit organizations that possess the characteristics just discussed. Afifuddin and Siti Nabiha (2010) highlighted the same - that religious based organizations lack ownership and the absence of a profit motive. As such, these organizations generally lack transparency and accountability to the public and their donors.

\section{Administration of Islamic affairs in Malaysia}

Malaysia consists of thirteen states (Selangor, Perak, Pulau Pinang, Perlis, Kedah, Kelantan, Terengganu, Pahang, Negeri Sembilan, Melaka, Johor, Sabah and Sarawak). According to the Ninth Schedule, of the Federal Constitution of Malaysia, Malay custom and Islamic law falls under the purview of each state jurisdiction except for the Federal Territory. Accordingly, any mat- ters that relate to the mosque are under the jurisdiction of the state government through the Islamic Religious Councils. As a consequence, the implementation of Islamic Law in each state varies. More importantly, the Islamic Religious Council of each state acts as a sole trustee of the mosques. However, each mosque has its own committee with a chairman to manage the mosque.

In general, mosques can be classified into four categories -state mosques, district mosques, subdistrict or qaryah mosques and private mosques (Siraj 2004). These four types of mosques are distinguished according to how they are managed and also where they are located. The first is the state mosque. These mosques are managed by the state government and there is only one state mosque for each state in Malaysia. In contrast, district mosques are located in various districts in the state and are also governed by the state government. The subdistrict or qaryah mosques are usually partially administered by the state government. Located in residential areas, qaryah mosques rely to a great extent on the public for funding. However, the state government still has the power to oversee the management of the qaryah mosques, even though its power over qaryah mosques is limited. Private mosques are those that are owned and managed by private organizations or individuals. Hence, the activities and programs of these mosques are not subject to the policies of the state or federal government (Siraj 2004).

In Terengganu, mosques are generally classified into two types -government mosques and qaryah mosques. Government mosques consist of the state mosque and the district mosques. There are 487 mosques in Terengganu, with 127 of these situated in Kuala Terengganu (www.jheatweb. terengganu.gov.my 2013). Out of the 127 
mosques in Kuala Terengganu, 113 are qaryah mosques.

\section{Sources of Funds and Management of Mosques}

Government and qaryah mosques in Terengganu are rather similar, as both rely on public donations. Generally, the government does not provide funds for these mosques. However, the government does provide funds for the repair and "improvement" of these mosques. The difference between the government mosques and qaryah mosques is the way the mosques are managed. According to Siraj (2004), there are three parties involved in the general administration of state mosques - the state Islamic Religious Department, the officers of the state mosques and the state mosque committees. The officers of the state mosques are considered as government servants and will receive a monthly salary paid by the State Government. However, qaryah mosques do not have officers managing the mosques, other than the imam (an Islamic leader, often the leader of a mosque) and bilal (the Muslim official of a mosque who calls for prayer). Hence, most of the committees in the qaryah mosques comprises of volunteers and are appointed by the members of the mosques at the annual general meeting. Even though qaryah mosques rely heavily on the public and volunteers, the administration and management of the mosques are still under the purview of the state government.

In terms of financial management, the financial guidelines of qaryah mosques are based on the guidelines stipulated in the enactment of Islamic affairs. According to the Terengganu Religious Officer, the income for qaryah mosques in Terengganu depends on the area but it is usually very minimal. Basically, the income is used to pay for the utilities. In general, the Islamic Religious Depart- ment requests qaryah mosques to have two main accounts, which comprise a general and a specific account. While the money from the general account is used to pay regular expenses, such as utility bills, the specific account is used for repairs to the mosque buildings. Separating the funds of the mosque into two accounts enables the treasurer to manage the funds according to their priority.

\section{Accounting and Accountability}

In Islam, accountability has broader economic and social objectives in which economics, politics, religious and social affairs, including accounting, fall under the jurisdiction of the divine law of Islam (Shari'ab) (Lewis 2006). As such, Islamic accountability is dual in nature - stressing accountability to one's fellow beings as well as accountability to Allah (God). Additionally, the word hisab is repeated more than eight times in different verses in the Quran, showing the important link between accounting, reporting and accountability (Nahar and Yaacob 2011). Budgeting and disclosure are necessary to ensure that accountability is properly (satisfactorily) discharged. While a budget helps to plan the utilization of the resources in an efficient and effective way, reporting communicates on how an organization utilizes the resources to the users. Having a budget encourages participants of the management team to discuss and plan the use of the resources (Parker 2002). Such involvement may indirectly motivate the team to properly discharge their accountability to the stakeholders, and, hence, lessen the risk of embezzlement in the organization. Lewis (2006) argued that in Islam truth, and fair and accurate disclosures are important elements of financial information. Adequate disclosure does not mean that all activities need to be included in the financial statement. Rather, 
Figure 1. Research Framework

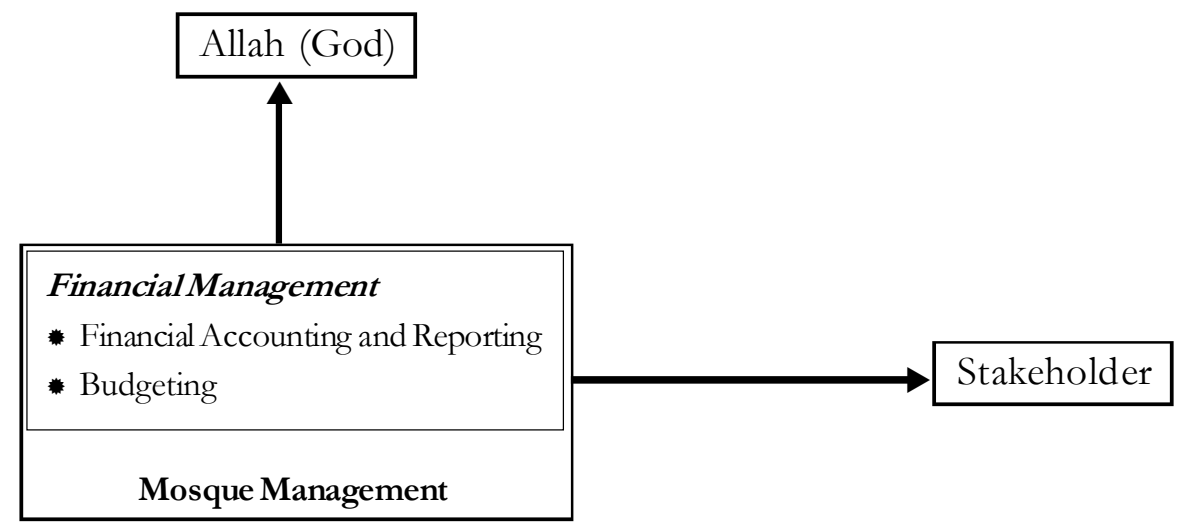

the financial statement only needs to contain relevant and significant information that is useful to its users. Both budgeting and reporting are important tools for humans to evaluate their sacred accountability to both their fellow humans and Allab (God) (Nahar and Yaacob 2011).

In the context of this study, the management of a mosque is accountable to $\mathrm{Al}$ lab and to the stakeholders. These stakeholders include the qaryah members, donors and the Islamic Religious Council/Department. Since accounting is one of the tools that reflect on accountability (Nahar and Yaacob 2011), to some extent, mosques may discharge their accountability through accounting practices. This study focuses on both the financial and management accounting aspects of accounting. The first is examined through financial reporting while the second concentrates on budgeting practices. According to various authors, both financial reporting and the use of budgets lead to better financial management and control (Duncan et al. 1999; Parker 2002; Bowrin 2004; Sulaiman et al. 2008; Jayasinghe and Soobaroyen 2009; Ventura and Daniel 2010; Enofe and Amaria 2011). The research framework is illustrated in Figure 1.

\section{Methods}

This study opts to use the mixed methodology of data collection, which combines quantitative and qualitative methods. The quantitative data collection method is based on the questionnaire while the qualitative method is grounded in the interview (Quinlan 2011; Sekaran and Bougie 2010; and Myers 2009). This multi-method of data collection is believed to give more credibility to the research instrument and to the data obtained. In fact, the collection of data from multiple sources and through multiple data collection methods will assist in producing good research (Sekaran 2003).

There were four stages involved in gathering our data. In the initial stage, the Terengganu Islamic Religious Department (JHEAT) was contacted to obtain the contact numbers for the qaryah mosques in Kuala Terengganu. The list given contained the contact numbers of the secretaries of the qaryah mosques in Kuala Terengganu. In the second stage of data collection each qaryah mosque on the list was contacted to inform them about the questionnaires and ask for their cooperation as a respondent. They were also required to give the mailing address to which 
the questionnaires should be posted. The questionnaires were then disseminated to the mosques in the sample as the third stage of data collection. Each mosque received an envelope containing a cover letter, the questionnaire, as well as a new envelope complete with a new stamp and the researcher's address to assist them in returning the questionnaire. They were given one month to respond, and after one month, a reminder was given by telephone. Based on the answers given in the questionnaire, semi-structured interviews were conducted to obtain additional information and to obtain more valuable data with regard to the accounting practices in the qaryah mosques. This was done by telephone and also face-to-face interviews. This happened in the fourth stage of our data collection.

The sample. There are 438 qaryah mosques in Terengganu. Kuala Terengganu has 113 qaryah mosques. However only 76 mosques have contact numbers and the questionnaires were distributed to these mosques (http:// jheatweb.terengganu.gov.my/).

The questionnaire. The questionnaire was divided into two parts. The first part covers general demographic information, while the second part focuses on answering the research questions. The questionnaire consists of both "fixed alternative" and "open ended" questions. As indicated in the introduction to the paper, the primary research questions of interest relate to whether qaryah mosques in Terengganu have proper financial reporting and a budgetary control system in place. A total of 26 sub-questions were developed which covered the accounting procedures, the qualification of the treasurer in the accounting field, the preparation of financial statements and annual reports, audit practices, the distribution of the financial information to the stakeholders (i.e., qaryah members, Islamic
Religious Department) and budgetary controls.

The questionnaire was initially prepared in English. There were several corrections in the second stage based on the comments given before finalizing it. Since the first language of the potential respondents is Malay, the final version of the questionnaire was then translated into Malay. The translation was done by referring to the work of Siraj (2004) and discussing with Malay and English language teachers, as well as an accounting teacher for the accounting terms. The Malay version of questionnaire was then "back translated" to English in order to ensure the meaning of each question had not deviated from the original version.

A pilot test, to assess the clarity of the questions, was then undertaken using both the English and Malay versions of the questionnaire. Fourteen sets of questionnaires, comprising seven sets of the Malay version and seven sets of the English version were distributed to six treasurers and one chairman of qaryah mosques in Selangor. They were given a choice as to whether to answer the questionnaire in English or Malay. The purpose of sending both versions was to detect which language they preferred. Based on the pilot test, minor amendments were made which included eliminating, rephrasing and inserting questions that were relevant to the research.

\section{Data Analysis}

Data obtained from the questionnaires were analyzed using SPSS statistics. Before they were keyed into the SPSS, the data underwent an editing and coding process. In the editing process, the returned questionnaires were examined for incompleteness and inconsistencies. Then, the following step was to 
code the responses. As most of the questions were closed questions, it was easy to do the coding process. For open-ended questions, the responses were compared and the common points were identified so that they were also easily encoded. The data were analyzed and interpreted by using a descriptive analyses technique.

\section{Analysis and Findings}

\section{Demographic Profile}

Of the 76 questionnaires distributed, 39 mosques responded, giving a response rate of 51.3 percent. Although there is no specific standard on the acceptable rate of response for surveys, a response rate that is above 50 percent may well be adequate, particularly in Malaysia. This is supported by Sekaran (2003) who believes that a 30 percent response rate for mailed surveys is considered acceptable. Most of the respondents were aged between 51 and 60 years old $(50 \%)$, followed by those between the ages of $41-50$ years $(28.9 \%)$. This comes as no surprise since the majority of people who go to the mosques consist of the elderly. This is supported by several respondents during the interviews, who indicated that it is the elderly that go to the mosques most regularly. The possible reasons for this are the fact that the mosque itself is usually not friendly to young people and added to this is the fact that the elderly are already retired and thus have more time to focus on religious matters. Or, perhaps, the elderly are generally more inclined to go to the mosque because they realize that death may be at their door. Only 2.6 percent of respondents were below 30 years old. We also found a large number of volunteers in our study. Similar findings were evident in studies by Duncan et al. (1999),
Wooten et al. (2003), Bowrin (2004) and Irvine (2005). This is because nonprofit organizations tend to be heavily dependent on volunteers.

The majority of the respondents were holding the position of "secretary" followed by "treasurer" and "chairman." Even though this study is concerned with the financial aspects of management and thus the relevant respondent should have been the treasurer, given the significant contributions of the secretary and the chairman towards the financial management of qaryah mosques, respondents holding such positions would also be deemed appropriate. Thus, one can observe that the accounting and financial management practices of qaryah mosques are not the sole responsibility of the treasurer alone - other committee members are also actively involved. As such, having a large percentage of respondents indicating that they are the secretary of the mosque may not impair the results in this study.

Due to the high involvement of volunteers and an improper segregation of duties between the committee members, it was to be expected that only 26.3 percent of the respondents claimed that their treasurer possessed qualification in accounting. However, the majority of them do not possess a tertiary level accounting qualification. The results appear to support prior research (Duncan et al. 1999; Duncan and Flesher 2002; Parker 2002; Wooten et al. 2003; Elson et al. 2007; Ventura and Daniel 2010; Enofe and Amaria 2011). This is somewhat worrying. In fact, during the interview sessions, they admitted that they have no accounting background, and, furthermore, some of them did not have any financial management training, as conducted by the State Islamic Religious Council and Terengganu Islamic Religious Department (IRD). Usually, one of the reasons why 
the committee refuses to join the training is because they feel that it is not really important and if they are forced by other committee members to go, they might think that the people do not trust them. However, the interviews conducted with the IRD revealed that, due to the shortage of staff in the IRD, the management training for the committees of qaryah mosques has not been conducted recently. Therefore, the committees, especially the treasurer may not have sufficient knowledge in administering the mosques. More importantly, the level of education of mosque committees might have an impact on the efficiency of the management of mosques (Ahmad et al. 2001). In the context of financial management, a treasurer with an accounting background is better able to manage the finances of the mosque more efficiently. Table 1 summarizes the results of the demographic information.

With regard to the source of funds, Table 2 shows that 48.71 percent of the respondents agree that the sources of funds for their mosques came from public donations, which is consistent with prior studies

\section{Table 1. Demographic Information}

Panel A: Age of respondents

\begin{tabular}{clcc}
\hline No. & Age & No. of respondents & Percentage \\
\hline 1. & below 30 years & 1 & 2.6 \\
2. & 30-40 years & 2 & 5.3 \\
3. & $41-50$ years & 11 & 28.9 \\
4. & $51-60$ years & 19 & 50.0 \\
5. & 61-70 years & 3 & 7.9 \\
6. & 71 and above & 2 & 5.3
\end{tabular}

Panel B: Employment status in the mosque

1. full time

$2 \quad 5.1$

2. part time

12.6

3. volunteer

36

\section{Panel C: Current position of the respondents}

1. Chairman 3

2. Secretary

$3-7.7$

3. Treasurer

Panel D: Accounting qualification of treasurer

1. Professional

2. Diploma

3. SPM

4. Course and training in accounting 
No. of
respondents

Percentage

1. Allocation from State Religious Department and Contribution from public/local communities

2. Allocation from State Religious Department and Contribution from public/local communities and Endowment (waqf)

3. Contributions from public/local communities only

4. Contributions from public/local communities and Endowment (waqf)

5. Contributions from public/local communities and Endowment (waqf) and rental

6. Contributions from public/local communities and rental
(Laughlin 1988; Ahmad et al. 2001; Wooten et al. 2003; Elson et al. 2007; Woodbine 1997; Jayasinghe and Soobaroyen 2009; Afifuddin and Siti Nabiha 2010). Consequently, this requires great financial control and accountability, as it involves managing public monies. Additionally, about 33 percent claimed that they receive income for the mosque from both the State Religious Department and public donations. As stated earlier, the sources of funds of mosques in Terengganu are heavily dependent on public donations. The Terengganu State Religious Department does not provide a monthly allocation to the mosques. However, the department will assist the management in providing funds for repairing and upgrading the mosques based on their requests. The committee for the mosque has to complete and submit the relevant form and the Terengganu Islamic Religious Department will appoint a person to examine the mosque and estimate the cost of repairing the building. Perhaps, that is why some of the respondents agree that their sources of funds come from a combination of an allocation from the State Religious Department and contributions from the public, even though they do not receive the funds from the State Religious Department regularly.

\section{Measurement of Financial Management Practices}

With reference to the research questions, this study not only investigates the financial disclosures and budgetary practices of the mosques, it also examines the strength of their practices. In determining the strength of the practices, the method used by Siraj (2004) has been adopted. Essentially, this method compares the number of control procedures implemented by individual qaryah mosques by calculating the average (AVE) using the following Formula 1. 
Formula 1. Average of Accounting Practices in Individual Qaryah Mosques

Summation of scores of control procedures for particular accounting practices implemented in each of the qaryah mosques

AVE:- $\longrightarrow 100$

Total number of control procedures for a particular accounting practice

Source:Siraj (2004)

The financial control system is said to be stronger if the number of control procedures implemented in a particular qaryah mosque is high, that is more than 60 percent. Finally, the overall implemented controls are evaluated using the average method (AVE-I) for all mosques. The average (AVE-I) helps to provide information concerning the general strength of a particular accounting practice in all qaryah mosques. The AVE-I is calculated using the following formula in Formula 2.

Formula 2. Average of Accounting Practices in Individual Qaryah Mosques

Summation of scores of control procedures for particular accounting practices implemented in each of the qaryah mosques

AVE-I:

$\begin{array}{ll} & \\ \text { Tutal number } & \times 100 \\ \text { of control } & \\ \text { mosques } & \text { procedures for } \\ & \text { a particular } \\ \text { accounting } & \text { practice }\end{array}$

Source:Siraj (2004)
Table 3.Classification of the Strength of the Internal Control System in Qaryah Mosques

\begin{tabular}{lll}
\hline No & $\begin{array}{l}\text { Scales for AVE-I } \\
\text { (\% of AVE-I) }\end{array}$ & $\begin{array}{l}\text { The Strength } \\
\text { of Control } \\
\text { System }\end{array}$ \\
\hline 1 & $0-24.9$ & Very Weak \\
2 & $25.0-49.9$ & Weak \\
3 & $50.0-59.9$ & Fair \\
4 & $60.0-84.9$ & Strong \\
5 & 85.0 and above & Very Strong \\
\hline
\end{tabular}

Source:Siraj (2004)

Siraj (2004) also developed a ranking scale to evaluate the strength of the financial management practices in state mosques, which has been adopted in the current study. The scales rank the financial management practice from "very weak" to "very strong" as in Table 3.

Overall, this study found that qaryab mosques in Kuala Terengganu do have financial reporting and budgetary practices. However, they have satisfactory (fair) control systems in financial accounting and reporting, but are weak in budgetary control systems. This actually answers our research questions highlighted in this study, where it has proven the existence of financial accounting and budgeting methods in qaryah mosques. Since this study extends the work of Siraj (2004), the results will be discussed in light of her study. 


\section{Financial Accounting and Reporting}

This section will answer the research Question 1 and 2:

RQ 1: Do mosques in Kuala Terengganu prepare accounts and disclosed it to the qaryah members?

RQ 2: What is the extent of disclosure practices by qaryah mosques?

As mentioned in the previous section, qaryah mosques do prepare accounts and disclose them to the qaryah members, which provides the answer to research Question 1. In answering research Question 2, our results revealed a "satisfactory" (fair) control in terms of disclosure practices. The results obtained here is slightly different from that of Siraj (2004) where she found state mosques had a less than satisfactory use for their reporting system. Table 4 summarizes the findings. It was found that 97.4 percent of the respondents prepared financial reports for their mosques and that most of them have income and expenditure as one of the items in the financial report. This is followed by receipts and payments, the cash flow and balance sheet. Perhaps, this is due to the nature of transactions that occurs most frequently in the mosques. Based on the informal inter-

Table 4. Results of Financial Reporting Practice

Panel A: Reporting System

\begin{tabular}{lll}
\hline No. Control & No. of Qaryah Mosques \\
& Implementing the Control Percentage \\
& (YES)
\end{tabular}

1. Does the mosque prepare any financial report?

$38 \quad 97.4$

2. Are the financial reports being audited?

$18 \quad 50.0$

3. Are the financial reports distributed to the qaryah members?

4. Are the financial reports made available to the qaryah members (e.g.: displayed on the mosque's notice board or mosque's website)?

5. Does the mosque prepare an annual report?

\section{Panel B: Type of Financial Statement}

\begin{tabular}{llcc}
\hline No. & Type of Financial Statement & No. of respondents & Percentage \\
\hline 1. & Balance Sheet & 10 & 25.64 \\
2. & Income and Expenditure & 23 & 58.97 \\
3. & Cash Flow & 13 & 33.33 \\
4. & Receipts and Payments & 16 & 41.03
\end{tabular}




\section{Table 4 (Contuinued)}

Panel C: Procedures and Manual Used in Preparing the Accounts

\begin{tabular}{|c|c|c|c|}
\hline No. & Control & $\begin{array}{l}\text { No. of Qaryah Mosques } \\
\text { Implementing the Control (YES) }\end{array}$ & Percentage \\
\hline 1. & $\begin{array}{l}\text { Does the mosque have any written } \\
\text { financial policy or procedures? }\end{array}$ & 22 & 56.4 \\
\hline 2. & $\begin{array}{l}\text { Are the written financial policy/ } \\
\text { procedures made available to all } \\
\text { mosque committee members and } \\
\text { administrative staff? }\end{array}$ & 25 & 67.6 \\
\hline \multicolumn{4}{|c|}{ Panel D: Reference Used to Prepare Financial Report } \\
\hline No. & Reference & No. of respondents & Percentage \\
\hline 1. & FRS & 3 & $8.1 \%$ \\
\hline 2. & Financial guideline issued by SIRC & 25 & $67.6 \%$ \\
\hline 3. & No standard & 9 & $24.3 \%$ \\
\hline
\end{tabular}

views, the transactions usually involve receipts of money and the disbursements generally relate to the payment of utilities. Accordingly, only the income and expenditure statement is prepared.

According to Malagueno et al. (2010), and Enofe and Amaria (2011), good financial record keeping, an annual audit and communication of the financial information to members are three elements that help organizations to be transparent and prevent corruption. In the case of the qaryah mosques examined here, 50 percent of the total respondents claimed that their financial reports were audited by a financial examiner. Although the existence of a financial examiner is required by the Administration of Muslim Law (Terengganu) Enactment 2001, results revealed that the financial examiners do not play their roles well. With regard to the disseminating of the financial report, Panel A of Table 4 shows only 24.3 percent of the respondents distributed the report to qaryah members. However, 81.1 percent made the financial report available to the qaryah members by displaying it on the notice board or website of the mosque. The results indicate that the majority of qaryah mosques in Kuala Terengganu do disclose their financial information and are transparent to the public. This is indeed commendable. It is such practices that may help the management to prevent embezzlement from happening in the mosques.

Despite having a majority of respondents preparing the financial report, only 59.5 percent prepare the annual report. The difference between the financial report and the annual report stems from the purpose they serve. The financial report, as the name suggests, provides financial information and presents it in terms of numbers and figures, whereas the annual report has a broader scope and provides more information than just num- 
bers. The annual report includes future plans and strategies of the organization, and a summary of activities apart from the financial statements. Thus, for small organizations like qaryah mosques where not much activity is conducted, it is possible to have fewer respondents who prepare an annual report because, to them, the financial report is enough to inform the qaryah members of how the mosque manages the funds given by the public. In addition, even though accounting is required in the Administration of Muslim Law (Terengganu) Enactment 2001, there is a lack of enforcement of this. As a result, some of the committees of the qaryah mosques are not aware of the requirements and use the previous accounting practice as a reference instead of using the financial guidelines issued by the enactment.

With regard to the procedural manuals, Table 4 shows that even though 56.4 percent stated that they have a financial policy and procedures, it is surprising to note that 67.6 percent claimed they made a written manual and procedures available to the committee members of qaryah mosques. This result highlights the disadvantage of using a mail questionnaire, as the interviewer's absence can lead to a misunderstanding of the questions by the respondents, and, hence, they use their own interpretation, which may not be quite correct (Pandiyan and Chandran 2011). In this case, since 56.4 percent have a written financial policy or procedures, the percentage of respondents making the procedures available (question 2) is supposed to be the same or lower than the percentage in question 1. Thus, to overcome this problem, interviews were conducted to gain more information regarding the financial manual or procedures.

Based on the interviews conducted, there is a lack of enforcement concerning the accounting practices of qaryah mosques. Consequently, the committees of the qaryah mosques use various formats of accounting practice grounded on their prior practices. It is also surprising to note that some of them are still confused concerning the format used and do not know what type of accounting record they should prepare. In line with this, the respondents were asked in the questionnaire about the reference they used to prepare the financial reports.

As presented in Table 4, 67.6 percent of the respondents use the financial guidelines issued by the State Islamic Religious Council (SIRC) and 24.3 percent prepared the financial report without any financial standards or procedures as a guideline. This confirms with what Boyce (1984) (as reported in Woodbine 1997) identified, in that much of the knowledge regarding accounting practices in religious organizations is acquired and transferred by oral processes. More importantly, the lack of enforcement concerning the usage of the financial guidelines issued by the SIRC will contribute to the variations in the accounting practice of qaryah mosques in Kuala Terengganu.

Based on the overall results, qaryah mosques still need some improvements in the areas of accounting practices and financial reporting in order to ensure better financial management.

\section{Budgetary Controls}

This section will discuss the answers for research Questions 3 and 4.
RQ 3: Do mosques in Kuala Terengganu prepare budgets?
RQ 4: What is the extent of budgetary practices by qaryah mosques?


Qaryah mosques in Kuala Terengganu do apply budgetary practices. However, the lower percentage of controls implemented in their budgeting practices resulted in weak scores of AVE-I, which indicates weak control of the practices among them. As presented in Table 5, only 27.8 percent of the respondents prepared a budget for annual expenditure. This result is consistent with the study of Parker (2002) who found loosely coupled budgetary control systems in churches in Australia. In contrast to this result, adequate control over budgetary practices in mosques was evidenced by Siraj (2004). This is expected since the state mosques, being larger in size, have proper management as compared to the qaryab mosques. Nevertheless, the result of this study points to the disadvantage of a questionnaire survey in as much as the findings for Questions 2, 4, 5, 7 and 8 are supposed to be the same or lower than the findings for Question 1, which is 27.8 percent (as the questions are meant for those who prepare the budget).

Although budgetary control is found to be weak from the survey, data from the interviews revealed that some of the qaryah mosques do actually prepare a simple budget. According to them the negative answer is because they have assumed that the question refers to a formal budget, as in government organizations and big companies. Additionally, they said that budgets are generally prepared for each activity which the mosque conducts that involves monies. However, some of the qaryah mosques do not really prepare a budget because, in their opinion, qaryah mosques are only involved in basic and regular financial transactions, like paying utility bills. Accordingly, they thought there was no need to prepare a budget. This is consistent with the results of the study conducted by Jayasinghe and Soobaroyen (2009). In that study they found that there was very little formal planning and budgeting involved within the Hindu temples and the treasurer informally prepares the budget more as a way to plan for significant cash payments rather than for approval or authorization. Budget practices are one of the important aspects of mosque management that should not be neglected, since it can help improve the financial management of the mosques. This is supported by Parker (2002) who suggests that even though budget practice is considered as "secular," it actually provides a regular medium for the discussions that can strengthen the organization's sacred agenda and the sustenance of its culture.

\section{Conclusion}

The study examined whether qaryah mosques in Kuala Terengganu have proper financial management (including reporting) and budgetary control system. This is in light of the fact that accounting is regarded as a tool that can aid the mosque management committees to discharge their duties with some accountability (Nahar and Yaacob 2011). The results revealed that qaryah mosques in Kuala Terengganu have indeed "satisfactory" control over financial accounting and reporting but the budgetary control is weak. What comes as a surprise is the fact that even though such mosques are required to have financial examiners examine their financial reports, a large number appear not to have their financial statements audited. Obviously, the financial examiner does not play an effective role, which may be due to the lack of enforcement. Most respondents also view accounting as an important tool in managing such organizations, that this accounting is a "welcome intrusion." Thus, this seems 
to support the contention that there is no division between the sacred and the secular in Islamic religious organizations. The findings here are consistent with those of Abdul Rahman (1998) and Sulaiman et al. (2008).

The results of this study should be interpreted in light of certain limitations. The first is the sample of 39 qaryah mosques. Although the number seems adequate if compared to other similar studies in Malaysia, this represents only 34.5 percent of the total number of qaryah mosques in Kuala Terengganu. Perhaps, non-respondents choose not to answer the questionnaire because they did not undertake any accounting of their funds. This is worrying since it exposes the organization to an element of distrust which will undermine the objective of the organization. The study also focused on one type of mosque in a specific location. Thus, future research could expand this study by including a larger sample size and to include the different types of mosques and from different states in $\mathrm{Ma}$ laysia. Secondly, since this study used a questionnaire survey, it does not possess the flexibility for a more detailed analysis. Thus, future research may wish to use a purely qualitative research method to study this research stream in detail.

Notwithstanding the above limitations, the study makes a pertinent contribution in several respects. The study has several implications for stakeholders and researchers. The results obtained here may provide an insight into the weaknesses as regards financial management of funds in mosques, and subsequently addressing the flaws so that this will benefit the stakeholders, especially donors, since their money will be managed and used properly. The findings also revealed a lack of enforcement on the failure of qaryah mosques to submit their accounts. Accordingly, it is in the interest of the stakeholders that the Terengganu Islamic Religious Council makes financial statements mandatory for every mosque and that the Terengganu Islamic Religious Department ensure that there is proper enforcement. In this, perhaps the Terengganu Islamic Religious Department can fully apply their 'e-collection' system. This might enable the treasurers of the mosques to report their financial statements and also assist Terengganu Islamic Religious Department in observing and obtaining the current information concerning the financial management of the mosques. Finally, it is good for the Terengganu Islamic Religious Council to publish financial guidelines on its website so that every mosque can refer to the same source. In this case, recognition should be given to the Islamic Religious Council of Singapore who created a very informative website in respect of Islamic affairs including mosque management. The website also provides mosque financial regulations as a reference. This might help increase the number of mosques preparing financial statements.

\section{References}

Abdul-Rahman, A. R., and A. Goddard. 1998. An interpretive inquiry of accounting practices in religious organizations. Financial Accountability and Management 14 (3): 183-201.

Afifuddin, H. B., and A. K. Siti-Nabiha. 2010. Towards good accountability: The role of accounting in Islamic Religious Organizations. World Academy of Science, Engineering and Technology: 1133-1139. 
Agus, A., M. S. Ahmad, and J. Muhammad. 2009. An empirical investigation on the impact of quality management on productivity and profitability: Associations and mediating effect. Contemporary Management Research 5 (1): 77-92.

Ahmad, J., S. Ahmad, M. Abd.-Majid, and W. Hairunnizam. 2001. Dana dan Harta Masjid di Malaysia: Ke arah Pengurusan Strategik [Funds and property of mosque in Malaysia: Towards a strategic management]. National Workshop on Capacity Building Towards Excellance in Econ. Research and Policy Formulation, 23-24 April 2001, Fakulti Ekonomi UKM.

Booth, P. 1993. Accounting in churches: A research framework and agenda. Accounting, Auditing and Accountability Journal 6 (4): 37-67.

Bowrin, A. R. 2004. Internal control in Trinidad and Tobago religious organizations. Accounting, Auditing and Accountability Journal17 (1):21-152.

Busby, D. 2004. Embezzlement in the church. The Clergy Journal (July/August): 25-28.

Busby, D. 2005. Preventing financial problems at your church. The Clergy Journal (February): 21-22.

Duncan, J. B., D. L. Flesher, and M. H. Stocks. 1999. Internal control system in US churches: An examination of the effects of church size and denomination on systems of internal control. Accounting, Auditing and Accountability Journal 12 (2): 142-163.

Duncan, J. B., and D. L. Flesher. 2002. Does your church have appropriate internal control for cash receipts? The National Public Accountant: 15-20.

Elson, R. J., S. O'Callaghan, and J. P. Walker. 2007. Corporate governance in religious organizations: A study of current practices in the local church. Academy of accounting and Financial Studies Journal 11 (1): 121-130.

Enofe, A., and P. Amaria. 2011. The role of the church denomination in financial accountability among religious organizations. International journal of Business, Accounting and Finance 5 (2): 87-104.

Hafidzin, S.N. 2011. Amil dapat 3 sebatan: Bekas imam mengaku songlap duit zakat RM 19,510 dijel empat tahun [Collector of tithes gets 3 strokes and four years prison: the former imam pleaded guilty to embezzling zakat money amounting to RM 19,510] (November 2). Harian Metro: 11.

Irvine, H. 2005. Balancing money and mission in a local church budget. Accounting, Auditing and Accountability Journal 18 (2): 211-237.

Jacobs, K. 2005. The sacred and the secular: examining the role of accounting in the religious context. Accounting, Auditing and Accountability Journal 18 (2): 189-210.

Jayasinghe, K., and T. Soobaroyen. 2009. Religious "spirit" and peoples' perceptions of accountability in Hindu and Buddhist religious organizations. Accounting, Auditing and Accountability Journal 22 (7): 997-1028.

Laughlin, R. C. 1988. Accounting in its social context: An analysis of the accounting systems of the church of England. Accounting, Auditing and Accountability Joumal, 1 (2): 19-42.

Lewis, M. K. 2006. Accountability and Islam. Fourth International Conference on Accounting and Finance in Transition, Adelaide, Australia, April 10-12.

Malagueno, R., C. Albrecht, C. Ainge, and N. Stephens. 2010. Accounting and corruption: A crosscountry analysis. Journal of Money Laundering Control 13 (4): 372-393.

Mohamed-Adil, M. A., Z. Mohd-Sanusi, N. A. Jaafar, M. M. Khalid, and A. Abd.-Aziz, A. 2012. Financial management practices of mosques in Malaysia. Proceedings. International Islamic Accounting and Finance Conference, 2012. Universiti Teknologi Mara, Malaysia. 
Morgan, G. G. 2009. New development: churches and charity accounting. Public Money and Management (November): 343-346.

Myers, M. D. 2009. Qualitative Research in Business and Management. London: Sage Publications Ltd.

Nahar H. S., and H. Yaacob. 2011. Accountability in the sacred context. The case of management, accounting and reporting of a Malaysian cash awqaf institution. Journal of Islamic Accounting and Business research 2 (2): 87-113.

Pandiyan, V., and V. G. R. Chandran. 2011. A Simple Guide for Business Undergraduates: Research Methods (2 $2^{\text {nd }}$ ed.). Shah Alam, University Publication Centre (UPENA).

Parker, L. D. 2002. Budgetary incrementalism in a Christian bureaucracy. Management Accounting Research 13: $71-100$.

Quinlan, C. 2011. Business Research Methods. UK: South Western CENGAGE Learning.

Said, J., A. Mohamed, Z. Mohd-Sanusi, S. N. Syed-Yusuf. 2013. Financial management practices in religious organizations: an empirical evidence of mosque in Malaysia. International Business Research 6 (7): 111-119.

Sekaran, U. 2003. Research Methods for Business: A Skill Building Approach. (4 $4^{\text {th }}$ ed.). NY: John Wiley and Sons.

Sekaran, U., and R. Bougie. 2010. Research Methods for Business: A Skill Building Approach (5 $5^{\text {th }}$ ed.). NY: John Wiley \& Sons.

Siraj, S. A. 2004. Financial management practices of state mosques in Peninsular Malaysia. Master's Thesis. International Islamic University Malaysia.

Sulaiman, M., S. A. Siraj, and S. H. Mohamed-Ibrahim. 2008. Internal control systems in West Malaysia’s State mosques. The American Journal of Islamic Social Sciences 25 (1): 63-81.

Throop, J. R. 2001. When a church faces embezzlement. The Clergy Journal (July): 27-28.

Ventura, M., and S. J. Daniel. 2010. Opportunities for fraud and embezzlement in religious organizations: An exploratory study. Journal of Forensic and Investigative Accounting 2 (issue 1): 1-35.

Woodbine, G. 1997. Cash controls within Christian churches: An exploration of the determinants. Asian Review of Accounting 5 (2): 21-37.

Wooten, T. C., J. W. Coker, and R. C. Elmore. 2003. Financial control in religious organizations: A status report. Nomprofit Management and Leadership 13 (4):343-365.

Wooten, T. C., J. Coker, and R. Elmore. 2005. Internal control is a good thing. Church Executive (October): 18-19.

\section{References from website:}

Enakmen Pentadbiran Hal Ehwal Agama Islam Terengganu. 2001. Retrieved January 8, 2012, from http:/ / www2.esyariah.gov.my/esyariah/mal/portalv1/ enakmen/State_Enact_Ori.nsf/

Jabatan Hal Ehwal Agama Terengganu (n.d.). Retrieved May 9, 2013, from http://jheatweb.terengganu.gov.my

Remmers, V. 2013. Hopewell Woman Arrested for Embezzling from Church (August 3). Retrieved October 1, 2013, from http://progress-index.com/news/hopewell-woman-arrested-for-embezzling-fromchurch-1.1530772. 